Correction

\title{
Correction: Bishop, H. et al. Driving among Adolescents with Autism Spectrum Disorder and Attention-Deficit Hyperactivity Disorder. Safety 2018, 4, 40
}

\author{
Haley Bishop *, Logan Boe, Despina Stavrinos and Jessica Mirman \\ Department of Psychology, University of Alabama at Birmingham, Birmingham, AL 35233, USA; \\ lboe@uab.edu (L.B.); dstavrin@uab.edu (D.S.); jhmirman@uab.edu (J.M.) \\ * Correspondence: haleyj89@uab.edu; Tel.: +205-975-0083
}

Received: 13 November 2018; Accepted: 14 November 2018; Published: 16 November 2018

The published version of the paper [1] had incorrect bibliographic information in Table 1 (e.g., author names; citations). The information has been corrected by the authorship team. 
Table 1. Literature Review Summary.

\begin{tabular}{|c|c|c|c|c|c|c|}
\hline \multicolumn{7}{|c|}{ Research Studies } \\
\hline Article & Type of Study & Objective & Participants & Key Findings & Limitations & MQI \\
\hline Almberg et al. 2015 & $\begin{array}{l}\text { Observational } \\
\text { Interview; } \\
\text { cross-sectional }\end{array}$ & $\begin{array}{l}\text { To explore driving } \\
\text { education } \\
\text { experienced by } \\
\text { individuals with ASD } \\
\text { or ADHD }\end{array}$ & $\begin{array}{ll}\text { - Individuals with ASD }(\mathrm{N}=19, \\
\\
\left.\mathrm{M}_{\text {age }}=20.7\right) \\
\text { Individuals with } \mathrm{ADHD}(\mathrm{N}=14, \\
\text { Mage }=20.6) \\
\text { - Driving instructors }(\mathrm{N}=9)\end{array}$ & $\begin{array}{l}\text { - ASD participants reported more driving } \\
\text { lessons and on-road tests } \\
\text { - ASD and ADHD groups reported different } \\
\text { challenges to obtaining a license }\end{array}$ & $\begin{array}{l}\text { - } \quad \text { Small sample size } \\
\text { - } \quad \text { wamorbidity of ADHD assessed } \\
\text { - } \quad \text { Questionnaire used not validated } \\
\end{array}$ & 0.68 \\
\hline Anstey et al. 2012 & $\begin{array}{l}\text { Observational; } \\
\text { cross-sectional }\end{array}$ & $\begin{array}{l}\text { To evaluate the } \\
\text { importance of } \\
\text { cognitive function for } \\
\text { the Capacity to Drive } \\
\text { Safely }\end{array}$ & $\begin{array}{l}\text { - Drivers between the ages of } 65-96 \\
(\mathrm{~N}=297)\end{array}$ & $\begin{array}{l}\text { - Capacity to Drive Safely declines as adults } \\
\text { age are associated with declines in spatial } \\
\text { and working memory, vision, and executive } \\
\text { functioning and speed }\end{array}$ & $\begin{array}{l}\text { - Sample bias towards a high } \\
\text { functioning group } \\
\text { - Screening measures may have been } \\
\text { too challenging for higher } \\
\text { risk drivers }\end{array}$ & 0.59 \\
\hline Ball et al. 2010 & $\begin{array}{c}\text { Randomized, } \\
\text { controlled trial (RCT) }\end{array}$ & $\begin{array}{l}\text { To test the effects of } \\
\text { cognitive training on } \\
\text { motor vehicle } \\
\text { collision involvement } \\
\text { in older drivers }\end{array}$ & $\begin{array}{l}\text { - Senior citizen drivers }(\mathrm{N}=908 \text {, } \\
\left.\mathrm{M}_{\mathrm{age}}=73.1\right)\end{array}$ & $\begin{array}{l}\text { Participants in the speed of processing and } \\
\text { the reasoning intervention had lower rates } \\
\text { of at-fault motor vehicle collisions than the } \\
\text { control group }\end{array}$ & $\begin{array}{l}\text { - No health rating scale or measure } \\
\text { of cumulative illness was available } \\
\text { for use }\end{array}$ & 0.78 \\
\hline Barkley et al. 2002 & $\begin{array}{l}\text { Observational; } \\
\text { cross-sectional }\end{array}$ & $\begin{array}{l}\text { To examine the } \\
\text { impact of ADHD on } \\
\text { multiple levels of } \\
\text { driving ability }\end{array}$ & $\begin{array}{ll}\text { - } & \text { Young adults with ADHD }(\mathrm{N} \\
& =105) \\
\text { - } & \text { Control adults }(\mathrm{N}=64, \text { age range } \\
\text { for groups combined }=17-28)\end{array}$ & $\begin{array}{l}\text { - Adults with ADHD reported more traffic } \\
\text { citations than controls } \\
\text { - ADHD adults made more errors than } \\
\text { controls on a visual reaction task } \\
\text { - Controls used safer driving habits than } \\
\text { ADHD adults }\end{array}$ & $\begin{array}{l}\text { - Examiners were not blind to group } \\
\text { - Participants were young, and older } \\
\text { drivers may have safer habits }\end{array}$ & 0.69 \\
\hline Biederman et al. 2007 & $\begin{array}{l}\text { Naturalistic; } \\
\text { cross-sectional }\end{array}$ & $\begin{array}{l}\text { To examine the } \\
\text { association between } \\
\text { ADHD and driving }\end{array}$ & $\begin{array}{ll}- & \text { Adults with ADHD }\left(\mathrm{N}=20 ; \mathrm{M}_{\mathrm{age}}\right. \\
& =32.0) \\
\text { - } & \text { Controls without ADHD }(\mathrm{N}=21 ; \\
& \left.\mathrm{M}_{\mathrm{age}}=27.2\right)\end{array}$ & $\begin{array}{l}\text { - ADHD participants were more likely to } \\
\text { collide with an obstacle than controls }\end{array}$ & $\begin{array}{l}\text { - Small, homogenous sample that } \\
\text { was referred to the study }\end{array}$ & 0.73 \\
\hline Bishop et al. 2017 & $\begin{array}{l}\text { Naturalistic; } \\
\text { cross-sectional }\end{array}$ & $\begin{array}{l}\text { To evaluate driving } \\
\text { performance around } \\
\text { hazards among } \\
\text { adolescents with ASD }\end{array}$ & $\begin{array}{ll}\text { - } & \text { Young adult drivers with ASD } \\
& (\mathrm{N}=16) \\
\text { - } & \text { Typically-developing controls } \\
\left(\mathrm{N}=16, \mathrm{M}_{\text {age }} \text { for groups }\right. \\
\text { combined }=23.17)\end{array}$ & $\begin{array}{l}\text { - Controls responded more quickly to } \\
\text { social hazards } \\
\text { - Participants with ASD showed no difference } \\
\text { in reaction time between hazard types }\end{array}$ & $\begin{array}{ll}\text { - } & \text { Small sample size } \\
\text { - } & \text { ASD participants were } \\
\text { high functioning } \\
\text { - Hazard types were not balanced on } \\
\text { incidental differences }\end{array}$ & 0.69 \\
\hline
\end{tabular}


Table 1. Cont

\begin{tabular}{|c|c|c|c|c|c|c|}
\hline \multicolumn{7}{|c|}{ Research Studies } \\
\hline Article & Type of Study & Objective & Participants & Key Findings & Limitations & MQI \\
\hline Borowsky et al. 2010 & $\begin{array}{l}\text { Observational; } \\
\text { cross-sectional }\end{array}$ & $\begin{array}{l}\text { To observe the effects } \\
\text { of age and experience } \\
\text { on identifying } \\
\text { hazards }\end{array}$ & $\begin{array}{ll}\text { - } & \text { Inexperienced drivers }(\mathrm{N}=21 \text {, age } \\
\text { range }=17-18) \\
\text { - } \\
\text { Experienced drivers }(\mathrm{N}=19 \text {, age } \\
\text { range }=22-30) \\
\text { Elderly-experienced drivers ( } \mathrm{N}= \\
\text { 16, age range }=65-72)\end{array}$ & $\begin{array}{l}\text { - Young drivers responded less sensitively to } \\
\text { unplanned hazards } \\
\text { More experienced drivers gazed more to the } \\
\text { right at T-intersections, while young drivers } \\
\text { gazed straight ahead }\end{array}$ & $\begin{array}{l}\text { - Small sample size } \\
\text { - Unclear study aims }\end{array}$ & 0.51 \\
\hline Brooks et al. 2016 & $\begin{array}{l}\text { Naturalistic; } \\
\text { cross-sectional }\end{array}$ & $\begin{array}{l}\text { To investigate the } \\
\text { motor aspects of } \\
\text { pre-driving skills in } \\
\text { young adults with } \\
\text { ASD }\end{array}$ & $\begin{array}{ll}\text { - Young adults with ASD }(\mathrm{N}=10 \text {, } \\
\left.\mathrm{M}_{\text {age }}=15.9\right) \\
\text { Neuro-typical controls }(\mathrm{N}=31 \text {, } \\
\left.\mathrm{M}_{\text {age }}=16.7\right)\end{array}$ & $\begin{array}{l}\text { - Participants with ASD needed more time to } \\
\text { complete the driving simulator tasks } \\
\text { Minimal performance differences were } \\
\text { observed between participants with ASD } \\
\text { and controls }\end{array}$ & - Small sample size & 0.66 \\
\hline Chee et al. 2015 & $\begin{array}{l}\text { Observational } \\
\text { interview; } \\
\text { cross-sectional }\end{array}$ & $\begin{array}{l}\text { To understand the } \\
\text { viewpoints of drivers } \\
\text { with ASD }\end{array}$ & $\begin{array}{l}\text { - } \quad \text { Young adults with ASD ( } \mathrm{N}=50 \text {, } \\
\left.\mathrm{M}_{\text {age }}=21.8\right) \\
\text { Typically developed adults }(\mathrm{N}=57 \text {, } \\
\left.\mathrm{M}_{\text {age }}=23.6\right)\end{array}$ & $\begin{array}{l}\text { - Some ASD participants preferred } \\
\text { non-driving modes of transportation } \\
\text { - Anxiety was found to be a barrier to driving } \\
\text { in the participants with ASD }\end{array}$ & $\begin{array}{l}\text { - Presence of ASD was self-reported } \\
\text { The ASD and the control groups } \\
\text { did not have equal driving statuses }\end{array}$ & 0.68 \\
\hline Corbett et al. 2009 & $\begin{array}{l}\text { Observational; } \\
\text { cross-sectional }\end{array}$ & $\begin{array}{l}\text { To compare and } \\
\text { contrast executive } \\
\text { functioning in } \\
\text { children with ASD, } \\
\text { ADHD, and typical } \\
\text { development. }\end{array}$ & $\begin{array}{ll}\text { - } & \text { Children with ASD }\left(\mathrm{N}=18, \mathrm{M}_{\mathrm{age}}=\right. \\
& 9.44) \\
\text { - } & \text { Children with } \mathrm{ADHD}(\mathrm{N}=18, \\
& \left.\mathrm{M}_{\mathrm{age}}=9.40\right) \\
\text { - } & \mathrm{TD} \text { children }\left(\mathrm{N}=18, \mathrm{M}_{\mathrm{age}}=9.56\right)\end{array}$ & $\begin{array}{l}\text { - Children with ADHD showed deficits in } \\
\text { vigilance, inhibition, and working memory } \\
\text { - Children with ASD showed deficits in } \\
\text { vigilance, response inhibition, cognitive } \\
\text { flexibility/switching, and working memory }\end{array}$ & $\begin{array}{l}\text { - Unknown if the sample represents } \\
\text { most children with ASD or ADHD } \\
\text { - Small sample size } \\
\text { - Some modest effects on the results } \\
\text { may have been due to } \\
\text { medication use }\end{array}$ & 0.67 \\
\hline Cox et al. 2012 & $\begin{array}{c}\text { Observational } \\
\text { interview }\end{array}$ & $\begin{array}{l}\text { To gain a better } \\
\text { understanding of } \\
\text { driving and ASD }\end{array}$ & $\begin{array}{l}\text { - Caregivers of young adults with } \\
\operatorname{ASD}(\mathrm{N}=123)\end{array}$ & $\begin{array}{l}\text { - Complex driving demands may be } \\
\text { problematic for this population } \\
\text { - Caregivers indicated that learning to drive is } \\
\text { a substantial challenge for their children }\end{array}$ & $\begin{array}{l}\text { - Responses from caregiver } \\
\text { Sample not representative of the } \\
\text { entire population of young adults } \\
\text { with ASD } \\
\text { - No verification of ASD diagnosis }\end{array}$ & 0.48 \\
\hline Cox et al. 2017 & RCT & $\begin{array}{l}\text { To investigate } \\
\text { whether virtual } \\
\text { reality driving } \\
\text { simulation training } \\
\text { improves ASD } \\
\text { driving performance }\end{array}$ & $\begin{array}{l}\text { Novice ASD drivers ( } \mathrm{N}=51, \mathrm{M}_{\mathrm{age}} \\
=17.96)\end{array}$ & $\begin{array}{l}\text { - Virtual reality driving simulation training } \\
\text { group improved driving and executive } \\
\text { functioning performance over control } \\
\text { training group }\end{array}$ & $\begin{array}{l}\text { - Small sample size } \\
\text { A control group of neuro-typical } \\
\text { drivers could have differentiated } \\
\text { the effects of ASK from that of } \\
\text { being a novice driver } \\
\text { - Greater emphasis of on-road } \\
\text { training during the training } \\
\text { interval could have } \\
\text { been encouraged }\end{array}$ & 0.66 \\
\hline
\end{tabular}


Table 1. Cont.

\begin{tabular}{|c|c|c|c|c|c|c|}
\hline \multicolumn{7}{|c|}{ Research Studies } \\
\hline Article & Type of Study & Objective & Participants & Key Findings & Limitations & MQI \\
\hline Crundall et al. 2010 & RCT & $\begin{array}{l}\text { To assess the effects of } \\
\text { commentary training } \\
\text { on learner drivers' } \\
\text { performance in a } \\
\text { simulator }\end{array}$ & $\begin{array}{l}\text { - Learner drivers }(\mathrm{N}=40 \text {, age range } \\
=17-25)\end{array}$ & $\begin{array}{l}\text { - The commentary trained group had fewer } \\
\text { crashes, reduced their speed on approach to } \\
\text { hazards sooner, and applied pressure to } \\
\text { brakes sooner than controls }\end{array}$ & $\begin{array}{ll}\text { - } & \text { Small sample size } \\
\text { - Confounds for commentary } \\
\text { training not accounted for (e.g., IQ) }\end{array}$ & 0.56 \\
\hline Curry et al. 2017 & Retrospective cohort & $\begin{array}{l}\text { To examine the } \\
\text { association between } \\
\text { ADHD, and licensing } \\
\text { and crash } \\
\text { involvement }\end{array}$ & $\begin{array}{ll}\text { - } & \text { Adolescents with ADHD }(\mathrm{N} \\
& =2479) \\
\text { - } & \text { Adolescents without ADHD }(\mathrm{N}= \\
15,865)\end{array}$ & $\begin{array}{l}\text { - Crash hazard among newly licensed drivers } \\
\text { - } \quad \text { Hith ADHD was } 36 \% \text { higher } \\
\text { Hazard ratios persisted over licensure }\end{array}$ & $\begin{array}{l}\text { Diagnosis relied on primary care } \\
\text { clinicians and not testing of } \\
\text { DSM-V standards } \\
\text { Driving exposure was } \\
\text { not examined } \\
\text { - Results may not be as generalizable } \\
\text { due to New Jersey's licensing age, } \\
\text { the urbanized area, and the higher } \\
\text { prevalence of ADHD in the studied } \\
\text { cohort relative to } \\
\text { US-based estimates }\end{array}$ & 0.64 \\
\hline Curry et al. 2018 & Retrospective cohort & $\begin{array}{l}\text { To compare the } \\
\text { proportion of } \\
\text { adolescents with and } \\
\text { without ASD who } \\
\text { acquire a learner's } \\
\text { permit and driver's } \\
\text { license }\end{array}$ & $\begin{array}{l}\text { - } \quad \mathrm{NJ} \text { residents born between } \\
1987-1995(\mathrm{~N}=52,172)\end{array}$ & $\begin{array}{l}\text { - } 1 / 3 \text { ASD individuals obtained a license } \\
\text { compared to } 83.5 \% \text { of other adolescents } \\
\text { ASD individuals obtain their license on a } \\
\text { median of } 9.2 \text { months later than } \\
\text { other adolescents } \\
\text { - } 89.7 \% \text { of individuals with ASD who } \\
\text { acquired a permit and were eligible to do so } \\
\text { obtained a license within } 2 \text { years }\end{array}$ & $\begin{array}{l}\text { - ASD diagnosis relied on electronic } \\
\text { health records } \\
\text { - New Jersey's licensing laws are } \\
\text { very unique and may not make the } \\
\text { results generalizable }\end{array}$ & 0.73 \\
\hline Daly et al. 2014 & $\begin{array}{l}\text { Observational; } \\
\text { cross-sectional }\end{array}$ & $\begin{array}{l}\text { To compare driving } \\
\text { history, preferences, } \\
\text { and behaviors of } \\
\text { adult drivers with } \\
\text { ASD with controls }\end{array}$ & $\begin{array}{l}\text { - Adults with ASD }\left(\mathrm{N}=78, \mathrm{M}_{\mathrm{age}}=\right. \\
\text { 32.9) } \\
\text { Adults without ASD }\left(\mathrm{N}=94, \mathrm{M}_{\mathrm{age}}\right. \\
=35.3)\end{array}$ & $\begin{array}{l}\text { Drivers with ASD reported lower ratings of } \\
\text { their ability to drive and higher numbers of } \\
\text { traffic accidents and citations } \\
\text { - Drivers with ASD reported higher numbers } \\
\text { of intentional violations, mistakes, and } \\
\text { slips/lapses }\end{array}$ & $\begin{array}{l}\text { - Data relied on anonymous } \\
\text { self-report and self-report } \\
\text { diagnosis of ASD } \\
\text { Only drivers with ASD with } \\
\text { internet access could complete } \\
\text { the survey }\end{array}$ & 0.7 \\
\hline Fabiano et al. 2011 & Pilot intervention & $\begin{array}{l}\text { To address } \\
\text { adolescents with } \\
\text { ADHD that have a } \\
\text { strong desire to drive }\end{array}$ & $\begin{array}{l}\text { - } 16 \text { and } 17 \text { year old adolescents with } \\
\text { ADHD }(\mathrm{N}=7)\end{array}$ & $\begin{array}{l}\text { - After the intervention, participants } \\
\text { decreased hard braking during } \\
\text { simulator drives } \\
\text { - } \\
\text { Parent-teen and family relationships, and } \\
\text { driving improved after the intervention }\end{array}$ & $\begin{array}{l}\text { - Small sample size of experienced, } \\
\text { licensed drivers } \\
\text { The baseline data for some } \\
\text { participants may have been } \\
\text { too brief } \\
\text { Potential confound with the } \\
\text { driving behaviors measured (e.g., } \\
\text { hard braking) and the season of } \\
\text { data collection (winter) }\end{array}$ & 0.64 \\
\hline
\end{tabular}


Table 1. Cont

\begin{tabular}{|c|c|c|c|c|c|c|}
\hline \multicolumn{7}{|c|}{ Research Studies } \\
\hline Article & Type of Study & Objective & Participants & Key Findings & Limitations & $\mathrm{MQI}$ \\
\hline Fabiano et al. 2016 & RCT & $\begin{array}{l}\text { To determine whether } \\
\text { the Supporting the } \\
\text { Effective Entry to the } \\
\text { Roadway program } \\
\text { improved family } \\
\text { functioning and } \\
\text { driving behavior }\end{array}$ & - $\quad$ Adolescents with ADHD ( $\mathrm{N}=172)$ & $\begin{array}{l}\text { - Parents in STEER were less negative at } \\
\text { post-treatment and 6-month follow-up } \\
\text { Teens in STEER reported lower levels of } \\
\text { risky driving behaviors at post-treatment } \\
\text { and 6-month follow-up }\end{array}$ & $\begin{array}{l}\text { - There was no control group that } \\
\text { received no intervention } \\
\text { - } \quad \text { Results may not generalize to } \\
\text { families with less } \\
\text { parental involvement } \\
\text { - Timing of assessments was not } \\
\text { aligned with the first month of } \\
\text { independent driving } \\
\text { - Medication was not } \\
\text { directly manipulated } \\
\text { STEER participants received more } \\
\text { attention and interaction with } \\
\text { study clinicians }\end{array}$ & 0.76 \\
\hline Fischer et al. 2007 & $\begin{array}{l}\text { Longitudinal, } \\
\text { observational; cohort }\end{array}$ & $\begin{array}{l}\text { To evaluate the } \\
\text { impact of ADHD on } \\
\text { driving ability }\end{array}$ & $\begin{array}{ll}\text { - } & \text { Children diagnosed as hyperactive } \\
& \left(\mathrm{N}=147, \mathrm{M}_{\text {age }}=21.1 \text { at follow-up }\right) \\
\text { - } & \text { Typically-developing control group } \\
& \left(\mathrm{N}=71, \mathrm{M}_{\text {age }}=20.5 \text { at follow-up }\right)\end{array}$ & $\begin{array}{l}\text { Hyperactive drivers were more often } \\
\text { ticketed for reckless driving, driving } \\
\text { without a license, hit and run crashes, and } \\
\text { more had license suspensions/revocations } \\
\text { - Cost of initial crash was greater for the } \\
\text { hyperactive group } \\
\text { - The hyperactive group employed less safe } \\
\text { driving practices }\end{array}$ & $\begin{array}{l}\text { - The examiner was not blind to } \\
\text { group membership } \\
\text { - Reliance on self-report data } \\
\text { - No correction was used in analysis } \\
\text { for experiment wise error }\end{array}$ & 0.56 \\
\hline Garner et al. 2012 & $\begin{array}{l}\text { Observational; } \\
\text { cross-sectional }\end{array}$ & $\begin{array}{l}\text { To understand the } \\
\text { relationship between } \\
\text { symptoms of ADHD } \\
\text { and adverse driving } \\
\text { outcomes }\end{array}$ & 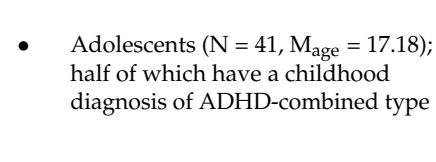 & $\begin{array}{l}\text { Inattention predicted more traffic citations, } \\
\text { more self-reported driving errors and } \\
\text { violations, and more motor vehicle crashes }\end{array}$ & $\begin{array}{l}\text { - } \quad \text { Small sample size } \\
\text { - } \quad \text { ADHDiance on self-report data of } \\
\text { - The study sample was self-referred }\end{array}$ & 0.69 \\
\hline Groom et al. 2015 & $\begin{array}{l}\text { Naturalistic; } \\
\text { cross-sectional }\end{array}$ & $\begin{array}{l}\text { To compare driving } \\
\text { performance of adults } \\
\text { with and without } \\
\text { ADHD }\end{array}$ & $\begin{array}{ll}\text { - } & \text { Adults with ADHD }\left(\mathrm{N}=22, \mathrm{M}_{\mathrm{age}}\right. \\
= & 31.4) \\
\text { - } & \text { Adult controls }\left(\mathrm{N}=21, \mathrm{M}_{\mathrm{age}}=\right. \\
& 34.0)\end{array}$ & $\begin{array}{l}\text { Participants with ADHD reported more } \\
\text { violations, lapses, and accidents } \\
\text { than controls } \\
\text { Participants with ADHD displayed higher } \\
\text { average speed and speeding, and showed } \\
\text { poorer vehicle control, greater levels of } \\
\text { frustration with other road users, and a } \\
\text { trend for less safe driving when changing } \\
\text { lanes in the driving simulator }\end{array}$ & $\begin{array}{l}\text { - Small sample size and few } \\
\text { female participants } \\
\text { - Study may have been } \\
\text { underpowered to find an effect } \\
\text { on errors }\end{array}$ & 0.67 \\
\hline
\end{tabular}


Table 1. Cont

\begin{tabular}{|c|c|c|c|c|c|c|}
\hline \multicolumn{7}{|c|}{ Research Studies } \\
\hline Article & Type of Study & Objective & Participants & Key Findings & Limitations & MQI \\
\hline Huang et al. 2012 & $\begin{array}{l}\text { Observational; } \\
\text { cross-sectional }\end{array}$ & $\begin{array}{l}\text { To compare the } \\
\text { characteristics of } \\
\text { driving and } \\
\text { non-driving teens } \\
\text { with higher } \\
\text { functioning ASD }\end{array}$ & $\begin{array}{l}\text { Parents of adolescents with ASD } \\
\text { between the ages of } 15 \text { and } 18 \text { who } \\
\text { drive }(\mathrm{N}=73) \text { and who do not } \\
\text { drive }(\mathrm{N}=175)\end{array}$ & $\begin{array}{l}\text { - } 63 \% \text { of adolescents currently drive or plan to } \\
\text { drive and } 29 \% \text { of teens that are age-eligible } \\
\text { to drive currently drive } \\
\text { More driving teens were in full-time } \\
\text { education, planned to attend college, and } \\
\text { held a paid job } \\
\text { Individualized education plans with driving } \\
\text { goals, indicators of functional status, and } \\
\text { parent experience with teaching teens to } \\
\text { drive predicted driving status in } \\
\text { the adolescent }\end{array}$ & $\begin{array}{l}\text { - Relied on parent report } \\
\text { - Selection bias may have occurred } \\
\text { due to the nature of the study }\end{array}$ & 0.68 \\
\hline Kenworthy et al. 2014 & RCT & $\begin{array}{l}\text { To evaluate the } \\
\text { effectiveness of } \\
\text { Unstuck and On } \\
\text { Target }\end{array}$ & $\begin{array}{l}\text { - 3rd-5th graders with ASD in the } \\
\text { Unstuck and On Target group }(\mathrm{N}= \\
\text { 47) or the social skills intervention } \\
\text { control group }(\mathrm{N}=20)\end{array}$ & $\begin{array}{l}\text { - Individuals in the Unstuck and On Target } \\
\text { group showed greater improvements in: } \\
\text { problem-solving, flexibility, } \\
\text { planning/organizing, and the ability to } \\
\text { follow rules, make transitions, and } \\
\text { be flexible } \\
\text { - Both groups made equal improvements in } \\
\text { social skills }\end{array}$ & $\begin{array}{ll}\text { - Small sample size not } \\
\text { followed longitudinally } \\
\text { - Did not evaluate specific } \\
\text { characteristics of } \\
\text { the interventionists } \\
\text { - A task used to measure executive } \\
\text { functioning had not been validated }\end{array}$ & 0.62 \\
\hline Kingery et al. 2015 & $\begin{array}{l}\text { Naturalistic; } \\
\text { cross-sectional }\end{array}$ & $\begin{array}{l}\text { To determine whether } \\
\text { ADHD- and } \\
\text { texting-related } \\
\text { driving impairments } \\
\text { are mediated by } \\
\text { extended visual } \\
\text { glances away from } \\
\text { the roadway }\end{array}$ & $\begin{array}{ll}-16 \text { and } 17 \text { year-olds with ADHD (N } \\
=28) \\
\text { - } 16 \text { and } 17 \text { year-olds without ADHD } \\
(\mathrm{N}=33)\end{array}$ & $\begin{array}{l}\text { - Adolescents with ADHD displayed more } \\
\text { visual inattention to the roadway during } \\
\text { driving simulation } \\
\text { - Increased lane variability in the ADHD } \\
\text { group was mediated by an increased } \\
\text { number of extended glances from } \\
\text { the roadway }\end{array}$ & $\begin{array}{l}\text { - The driving simulator may not } \\
\text { represent actual driving } \\
\text { - The conversation conditions may } \\
\text { not have represented } \\
\text { actual conversations } \\
\text { - Cognitive distraction was } \\
\text { not captured }\end{array}$ & 0.64 \\
\hline Klauer et al. 2006 & Naturalistic & $\begin{array}{l}\text { To evaluate driver } \\
\text { inattention using the } \\
\text { driving data collected } \\
\text { in the 100-Car } \\
\text { Naturalistic Driving } \\
\text { Study }\end{array}$ & - 100 cars & 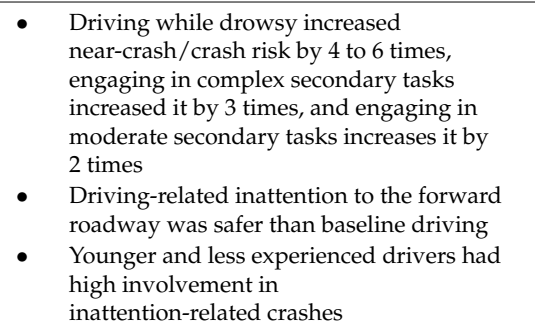 & $\begin{array}{l}\text { - Conducted in only one } \\
\text { metropolitan area } \\
\text { - Secondary tasks were not } \\
\text { controlled during analysis and } \\
\text { duration of secondary tasks was } \\
\text { not analyzed } \\
\text { - No continuous audio feed } \\
\text { was present }\end{array}$ & 0.74 \\
\hline
\end{tabular}


Table 1. Cont

\begin{tabular}{|c|c|c|c|c|c|c|}
\hline \multicolumn{7}{|c|}{ Research Studies } \\
\hline Article & Type of Study & Objective & Participants & Key Findings & Limitations & MQI \\
\hline Lanzi 2005 & Pilot intervention & $\begin{array}{l}\text { To develop and } \\
\text { implement a learner's } \\
\text { license program for } \\
\text { adolescents with mild } \\
\text { mental retardation or } \\
\text { other cognitive } \\
\text { limitations }\end{array}$ & $\begin{array}{l}\text { Adolescent students in Alabama } \\
\text { with cognitive limitations ( } \mathrm{N}=157)\end{array}$ & $\begin{array}{l}\text { - } 78 \% \text { of students that had an opportunity to } \\
\text { take the Alabama Learner's License Test } \\
\text { passed the test }\end{array}$ & $\begin{array}{ll}\text { - } & \text { No control group } \\
\text { Driving ability was not assessed }\end{array}$ & 0.49 \\
\hline Matthews et al. 1991 & $\begin{array}{l}\text { Observational; } \\
\text { cross-sectional }\end{array}$ & $\begin{array}{l}\text { To map associations } \\
\text { between individual } \\
\text { differences in driver } \\
\text { stress and personality } \\
\text { variables }\end{array}$ & $\begin{array}{l}-\quad \text { Study 1: Adult drivers }(\mathrm{N}=159) \\
\text { - } \quad \text { Study 2: Adult drivers }(\mathrm{N}=44) \\
\quad \quad \text { Study 3: Adult drivers }(\mathrm{N}=49) \\
\text { - }\end{array}$ & $\begin{array}{l}\text { - General driver stress was positively } \\
\text { correlated with neuroticism, minor crash } \\
\text { involvement, and higher frequency of daily } \\
\text { hassles and aggressiveness } \\
\text { - } \quad \begin{array}{l}\text { Higher driver stress was associated with } \\
\text { poorer self-rated attention }\end{array} \\
\text { - Driver stress was associated with stressed } \\
\text { mood states }\end{array}$ & $\begin{array}{l}\text { - No causal interpretations can } \\
\text { be made } \\
\text { - All data was self-report data }\end{array}$ & 0.57 \\
\hline Mayhew et al. 2003 & Retrospective cohort & $\begin{array}{l}\text { To examine changes } \\
\text { in collisions among } \\
\text { new drivers }\end{array}$ & - $\quad$ Novice drivers $(\mathrm{N}=40,661)$ & $\begin{array}{l}\text { Length of time since licensure is associated } \\
\text { with decreasing crash rates, with declines } \\
\text { most pronounced in the first } 6 \text { months } \\
\text { The involvement of certain crash types } \\
\text { decline more rapidly than other crash types }\end{array}$ & $\begin{array}{l}\text { - The results do not control for } \\
\text { different levels of exposure for } \\
\text { young and older novice drivers to } \\
\text { the risk of a collision } \\
\text { Reasons for differential changes in } \\
\text { crash patterns for young and older } \\
\text { novice drivers are unknown }\end{array}$ & 0.55 \\
\hline Merkel et al. 2016 & $\begin{array}{l}\text { Naturalistic; } \\
\text { cross-sectional }\end{array}$ & $\begin{array}{l}\text { To assess on-road } \\
\text { driving behavior in a } \\
\text { sample of young } \\
\text { adult drivers with } \\
\text { ADHD }\end{array}$ & $\begin{array}{l}\text { - Young adults with ADHD ( } \mathrm{N}=17, \\
\left.\mathrm{M}_{\text {age }}=20.71\right) \\
\text { - Young adults without } \mathrm{ADHD}(\mathrm{N}= \\
\left.19, \mathrm{M}_{\text {age }}=21.16\right)\end{array}$ & $\begin{array}{l}\text { - Drivers with ADHD were more likely to } \\
\text { have more crashes, minor events, and } \\
\text { g-force events } \\
\text { G-force events for drivers with ADHD were } \\
\text { more risky and illegal, } \\
\text { hyperactive/impulsive, and had more } \\
\text { distracted behaviors }\end{array}$ & $\begin{array}{l}\text { - The video recording device was } \\
\text { only active, therefore behaviors } \\
\text { were only analyzed, during } \\
\text { g-force events } \\
\text { Only young adults with ADHD } \\
\text { that had a minimum record of } \\
\text { driving difficulty were recruited } \\
\text { for the study }\end{array}$ & 0.77 \\
\hline Moudon et al. 2011 & Retrospective cohort & $\begin{array}{l}\text { To estimate the odds } \\
\text { of a pedestrian dying } \\
\text { or being disabled as a } \\
\text { result of a collision } \\
\text { with a motor vehicle }\end{array}$ & $\begin{array}{l}\text { - Pedestrians involved in a collision } \\
\text { on state routes }(\mathrm{N}=757) \text { and on } \\
\text { city streets }(\mathrm{N}=2457)\end{array}$ & $\begin{array}{l}\text { - } 7.4 \% \text { of pedestrians involved in collisions } \\
\text { died and } 19.0 \% \text { obtained a disabling injury, } \\
\text { with older pedestrians having an increased } \\
\text { risk of both outcomes }\end{array}$ & $\begin{array}{l}\text { - The data only estimates injury } \\
\text { severity and does not estimate } \\
\text { collision frequency } \\
\text { Data on pedestrians' age and } \\
\text { gender, and on vehicle descriptive } \\
\text { (e.g., vehicle type, vehicular } \\
\text { speeds) were not complete }\end{array}$ & 0.64 \\
\hline
\end{tabular}


Table 1. Cont

\begin{tabular}{|c|c|c|c|c|c|c|}
\hline \multicolumn{7}{|c|}{ Research Studies } \\
\hline Article & Type of Study & Objective & Participants & Key Findings & Limitations & MQI \\
\hline Narad et al. 2013 & $\begin{array}{l}\text { Naturalistic; } \\
\text { cross-sectional }\end{array}$ & $\begin{array}{l}\text { To investigate the } \\
\text { risks of adolescence, } \\
\text { ADHD, and } \\
\text { distracted driving on } \\
\text { driving performance }\end{array}$ & $\begin{array}{ll}\text { - } & \text { Adolescents with ADHD ( }=28, \\
& \left.\mathrm{M}_{\text {age }}=16.86\right) \\
\text { Adolescents without } \mathrm{ADHD}(\mathrm{N}= \\
\left.33, \mathrm{M}_{\text {age }}=17.14\right)\end{array}$ & $\begin{array}{l}\text { - Adolescents with ADHD reported less } \\
\text { driving experience and a higher proportion } \\
\text { of driving violations } \\
\text { Adolescents with ADHD drove with more } \\
\text { variability in speed and lane position during } \\
\text { simulated drives } \\
\text { All drivers drove with increased variability } \\
\text { in speed and lane position during the } \\
\text { texting condition }\end{array}$ & $\begin{array}{l}\text { - Simulator performance may not } \\
\text { represent real-world } \\
\text { driving behaviors } \\
\text { - } \quad \text { Driving settings were limited to } \\
\text { suburban and urban roadways } \\
\text { - The ADHD sample may not have } \\
\text { been representative of the } \\
\text { ADHD population }\end{array}$ & 0.77 \\
\hline Patrick et al. 2018 & $\begin{array}{l}\text { Naturalistic; } \\
\text { cross-sectional }\end{array}$ & $\begin{array}{l}\text { To examine } \\
\text { differences in driving } \\
\text { behavior between } \\
\text { young adults with } \\
\text { and without ASD }\end{array}$ & $\begin{array}{ll}\text { - } & \text { Young adults with ASD }(\mathrm{N}=50, \\
& \left.\mathrm{M}_{\text {age }}=19.79\right) \\
\text { - } & \text { Typically-developing young adults } \\
\left(\mathrm{N}=50, \mathrm{M}_{\mathrm{age}}=19.73\right)\end{array}$ & $\begin{array}{l}\text { Drivers with ASD had more difficulty with } \\
\text { speed and lane management in the } \\
\text { driving simulator } \\
\text { Engaging in secondary tasks impacted } \\
\text { driving behavior more for drivers with ASD }\end{array}$ & $\begin{array}{l}\text { - Controls reported more previous } \\
\text { driving experience than the } \\
\text { participants with ASD } \\
\text { - The sample did not include many } \\
\text { licensed drivers } \\
\text { - The order of the secondary tasks } \\
\text { were not counterbalanced }\end{array}$ & 0.71 \\
\hline Poulsen et al. 2010 & RCT & $\begin{array}{l}\text { To develop a hazard } \\
\text { perception training } \\
\text { intervention for } \\
\text { drivers with ADHD } \\
\text { symptoms }\end{array}$ & $\begin{array}{l}\text { - Young adults with ADHD in a } \\
\text { hazard perception training group } \\
\left(\mathrm{N}=20, \mathrm{M}_{\text {age }}=22.2\right) \text { or an } \\
\text { intervention control group }(\mathrm{N}=20, \\
\left.\mathrm{M}_{\mathrm{age}}=26.5\right)\end{array}$ & $\begin{array}{l}\text { - Participants in the hazard perception } \\
\text { training group displayed larger } \\
\text { improvements in hazard perception } \\
\text { response times }\end{array}$ & $\begin{array}{ll}\text { - } & \text { Small sample of } \\
\text { self-referred drivers } \\
\text { - } & \text { Effects of the intervention on } \\
\text { specific subtypes of ADHD were } \\
\text { not studied } \\
\text { - Participants were not clinically } \\
\text { assessed for ADHD }\end{array}$ & 0.71 \\
\hline Reimer et al. 2010 & $\begin{array}{l}\text { Naturalistic; } \\
\text { cross-sectional }\end{array}$ & $\begin{array}{l}\text { To explore the impact } \\
\text { of cognitive } \\
\text { distractions on young } \\
\text { drivers with and } \\
\text { without ADHD }\end{array}$ & $\begin{array}{l}\text { - Young adults with ADHD }(\mathrm{N}=25, \\
\text { Mage }=20.56) \\
\text { Young adults without ADHD ( }= \\
\left.35, \mathrm{M}_{\text {age }}=20.65\right)\end{array}$ & $\begin{array}{l}\text { Drivers with ADHD had more difficulty } \\
\text { driving with a hands-free device in a } \\
\text { simulator, but did not show } \\
\text { decreased performance } \\
\text { Drivers with ADHD exhibited a larger } \\
\text { decline in performance when driving with a } \\
\text { secondary task in a low demand setting }\end{array}$ & $\begin{array}{l}\text { - There were no baseline } \\
\text { performance measures of the } \\
\text { cognitive tasks } \\
\text { - Order of secondary tasks and } \\
\text { environments were } \\
\text { not counterbalanced }\end{array}$ & 0.77 \\
\hline Reimer et al. 2013 & $\begin{array}{l}\text { Naturalistic; } \\
\text { cross-sectional }\end{array}$ & $\begin{array}{l}\text { To explore driving } \\
\text { behavior and visual } \\
\text { attention in young } \\
\text { adult drivers with } \\
\text { high functioning ASD }\end{array}$ & $\begin{array}{l}\text { - } \quad \text { Young adults with HF-ASD }(\mathrm{N}= \\
\left.20, \mathrm{M}_{\mathrm{age}}=20.20\right) \\
\text { - } \\
=20 \mathrm{mmunity} \text { controls }\left(\mathrm{N}=20, \mathrm{M}_{\mathrm{age}}\right. \\
=20\end{array}$ & $\begin{array}{l}\text { - Individuals with HF-ASD exhibited a higher } \\
\text { and unvaried heart rate } \\
\text { Individuals with HF-ASD showed a gaze } \\
\text { pattern suggestive of a diversion of visual } \\
\text { attention away from high stimulus areas of } \\
\text { the roadway }\end{array}$ & $\begin{array}{l}\text { - Small sample size } \\
\text { Simulator driving behavior in } \\
\text { individuals with HF-ASD may not } \\
\text { be generalizable to actual } \\
\text { driving behavior }\end{array}$ & 0.66 \\
\hline
\end{tabular}


Table 1. Cont

\begin{tabular}{|c|c|c|c|c|c|c|}
\hline \multicolumn{7}{|c|}{ Research Studies } \\
\hline Article & Type of Study & Objective & Participants & Key Findings & Limitations & MQI \\
\hline Sheppard et al. 2010 & $\begin{array}{l}\text { Observational; } \\
\text { cross-sectional }\end{array}$ & $\begin{array}{l}\text { To investigate hazard } \\
\text { perception in young } \\
\text { adults with and } \\
\text { without ASD }\end{array}$ & $\begin{array}{ll}\text { - } & \text { Young adults with ASD }(\mathrm{N}=23, \\
& \left.\mathrm{M}_{\mathrm{age}}=18.55\right) \\
\text { - } & \text { Comparison controls }\left(\mathrm{N}=21, \mathrm{M}_{\mathrm{age}}\right. \\
& =18.83)\end{array}$ & $\begin{array}{l}\text { Participants with ASD identified fewer } \\
\text { social hazards and were slower to respond } \\
\text { to hazards }\end{array}$ & $\begin{array}{l}\text { Using videos to test perceptions } \\
\text { may not represent } \\
\text { real-life situations }\end{array}$ & 0.62 \\
\hline Sheppard et al. 2016 & $\begin{array}{l}\text { Observational; } \\
\text { cross-sectional }\end{array}$ & $\begin{array}{l}\text { To explore attentional } \\
\text { patterns in } \\
\text { individuals with and } \\
\text { without ASD }\end{array}$ & $\begin{array}{l}\text { - Young adults with ASD ( } \mathrm{N}=18 ; \\
\left.\mathrm{M}_{\mathrm{age}}=18.79\right) \\
\text { Comparison controls }\left(\mathrm{N}=17, \mathrm{M}_{\mathrm{age}}\right. \\
=18.19)\end{array}$ & $\begin{array}{l}\text { - Participants with ASD were slower to orient } \\
\text { gaze to hazards } \\
\text { Greater attentional capture in the time } \\
\text { preceding the hazards' onset was associated } \\
\text { with lower verbal IQ }\end{array}$ & $\begin{array}{l}\text { - None of the participants } \\
\text { were licensed } \\
\text { The hazard perception test } \\
\text { performance is not representative } \\
\text { of individuals with driving } \\
\text { training/experience } \\
\text { - The sample was only male }\end{array}$ & 0.62 \\
\hline Sobanski et al. 2008 & $\begin{array}{l}\text { Nonrandomized } \\
\text { control trial }\end{array}$ & $\begin{array}{l}\text { To assess history of } \\
\text { driving and } \\
\text { determine whether } \\
\text { pharmacotherapy } \\
\text { improves driving } \\
\text { related cognitive } \\
\text { functions in adults } \\
\text { with ADHD }\end{array}$ & $\begin{array}{ll}\text { - } & \text { Adults with ADHD ( } \mathrm{N}=27, \mathrm{M}_{\text {age }} \\
& =34.3) \\
\text { - } & \text { Control adults }\left(\mathrm{N}=27, \mathrm{M}_{\text {age }}=34.3\right)\end{array}$ & $\begin{array}{l}\text { Adults with ADHD drove more per year, } \\
\text { were registered and fined by traffic } \\
\text { authorities more, were involved in more } \\
\text { accidents, and self-reported driving more } \\
\text { insecure and hectic } \\
\text { Methylphenidate treatment improved } \\
\text { information processing, visual orientation, } \\
\text { and sustained visual attention }\end{array}$ & $\begin{array}{l}\text { - Small sample size and controls } \\
\text { recruited from the authors' circle } \\
\text { of friends } \\
\text { - Investigators were not blind to } \\
\text { medication or control status } \\
\text { - Some data was collected } \\
\text { from self-reports }\end{array}$ & 0.65 \\
\hline Wade et al. 2015 & RCT & $\begin{array}{l}\text { To test a } \\
\text { gaze-contingent } \\
\text { driving intervention }\end{array}$ & $\begin{array}{l}\text { - Adolescents with ASD in the } \\
\text { gaze-contingent intervention group } \\
\left(\mathrm{N}=6 ; \mathrm{M}_{\mathrm{age}}=14.65\right) \text { or a } \\
\text { performance-based control group } \\
\left(\mathrm{N}=6 ; \mathrm{M}_{\mathrm{age}}=15.93\right)\end{array}$ & $\begin{array}{l}\text { - Participants in the gaze-contingent group } \\
\text { showed a lowered and left-shifted gaze } \\
\text { - Participants in the control group showed a } \\
\text { decrease in trial failures pre-test to post-test }\end{array}$ & $\begin{array}{l}\text { Very small sample size and more } \\
\text { in-depth analysis of the data } \\
\text { is required }\end{array}$ & 0.54 \\
\hline \multicolumn{7}{|c|}{ Review Papers } \\
\hline Article & Review Type & Objective & \multicolumn{2}{|r|}{ Outcomes } & \multicolumn{2}{|l|}{ Limitations } \\
\hline Barkley and Cox 2007 & Literature Review & $\begin{array}{l}\text { Review driving risks } \\
\text { associated with } \\
\text { ADHD }\end{array}$ & $\begin{array}{ll}\text { - } & \text { Risks for driving offenses and crash } \\
& \text { ADHD symptoms } \\
\text { - } & \text { Adults with ADHD are at increased } \\
\text { - } & \text { Drivers with high aggression have b } \\
& \text { disorders, such as ADHD } \\
\text { - } & \text { MPH medications improve driving }\end{array}$ & $\begin{array}{l}\text { es were increased among children with more severe } \\
\text { risk for adverse driving outcomes } \\
\text { een found to have a higher prevalence of psychiatric } \\
\text { performance in adolescents with ADHD }\end{array}$ & $\begin{array}{l}\text { - More research is needed on how } m \\
\text { that MPH, impacts driving perforr } \\
\text { - Other treatments need to be evalu } \\
\text { efficacy of improving driving outc }\end{array}$ & $\begin{array}{l}\text { ation, other } \\
\text { on their }\end{array}$ \\
\hline
\end{tabular}


Table 1. Cont

\begin{tabular}{|c|c|c|c|c|}
\hline \multicolumn{5}{|c|}{ Research Studies } \\
\hline Article & Type of Study & Objective & Key Findings & Limitations \\
\hline Elander et al. 1993 & Literature Review & $\begin{array}{l}\text { To review } \\
\text { methodological issues } \\
\text { on the study of } \\
\text { differential crash } \\
\text { involvement }\end{array}$ & $\begin{array}{l}\text { - Hazard perception latency plays a role in how driving skill contributes to crash risk } \\
\text { Driving styles of driving faster and willingness to commit driving violations increase } \\
\text { crash risk and may be explained in terms of personality and antisocial motivation }\end{array}$ & $\begin{array}{l}\text { - Driver training and testing procedures need to } \\
\text { be improved } \\
\text { A more comprehensive theory of crash risk needs } \\
\text { to be developed }\end{array}$ \\
\hline Lindsay 2016 & $\begin{array}{c}\text { Systematic Literature } \\
\text { Review }\end{array}$ & $\begin{array}{l}\text { To review the } \\
\text { literature on factors } \\
\text { affecting driving for } \\
\text { people with ASD }\end{array}$ & $\begin{array}{l}\text { - Many people with ASD encounter challenges in obtaining a driver's license, driving } \\
\text { confidence, and driving performance } \\
\text { Direct communication, encouraging coping mechanisms, breaking down tasks, and } \\
\text { providing regular and consistent driving lessons are all useful strategies when teaching } \\
\text { people with ASD to drive }\end{array}$ & $\begin{array}{l}\text { - } \quad \text { More rigorous research is needed } \\
\text { - Penfounds not often accounted for } \\
\text { and their experience is inadequate }\end{array}$ \\
\hline Wilson et al. 2018 & Literature Review & $\begin{array}{l}\text { To review driving } \\
\text { behaviors of } \\
\text { individuals with ASD }\end{array}$ & $\begin{array}{l}\text { - Individuals with ASD drive differently than neuro-typical individuals } \\
\text { - Individuals with ASD have shortcomings on skills related to driving, but how this } \\
\text { affects their safety and the safety of other on the road is unclear } \\
\text { - Training programs can improve skills related to driving }\end{array}$ & $\begin{array}{l}\text { - There are few ASD-specific learner training } \\
\text { programs available } \\
\text { Many studies use data from observations in } \\
\text { driving simulator and/or virtual reality settings, or } \\
\text { use self-report driving data }\end{array}$ \\
\hline
\end{tabular}


The authors apologize for any inconvenience caused to the readers by these changes. The changes do not affect the scientific results. The original manuscript will be updated and will remain online on the article webpage, with a reference to this correction.

\section{References}

1. Bishop, H.; Boe, L.; Stavrinos, D.; Mirman, J. Driving among Adolescents with Autism Spectrum Disorder and Attention-Deficit Hyperactivity Disorder. Safety 2018, 4, 40. [CrossRef] 